\title{
Inequality in times of pandemics: How online media are starting to treat the economic consequences of the coronavirus crisis
}

\author{
Javier Odriozola-Chéné; Javier Díaz-Noci; Ana Serrano-Tellería; Rosa Pérez- \\ Arozamena; Laura Pérez-Altable; Juan Linares-Lanzman; Lucía García-Carretero; \\ Luis-Mauricio Calvo-Rubio; Manuel Torres-Mendoza; Adolfo Antón-Bravo
}

How to cite this article:

Odriozola-Chéné, Javier; Díaz-Noci, Javier; Serrano-Tellería, Ana; Pérez-Arozamena, Rosa; Pérez-Altable, Laura; Linares-Lanzman, Juan; García-Carretero, Lucía; Calvo-Rubio, Luis-Mauricio; Torres-Mendoza, Manuel; Antón-Bravo, Adolfo (2020). "Inequality in times of pandemics: How online media are starting to treat the economic consequences of the coronavirus crisis". Profesional de la información, v. 29, n. 4, e290403. https://doi.org/10.3145/epi.2020.jul.03

Manuscript received on May $26^{\text {th }} 2020$ Accepted on June $6^{\text {th }} 2020$

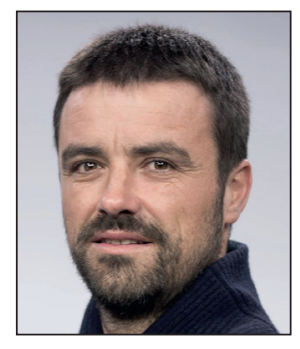

Javier Odriozola-Chéné https://orcid.org/0000-0002-8595-1950

Universidad Europea del Atlántico Facultad de Ciencias Sociales y Humanidades

Isabel Torres, 21. 39011 Santander, Spain javier.odriozola@uneatlantico.es

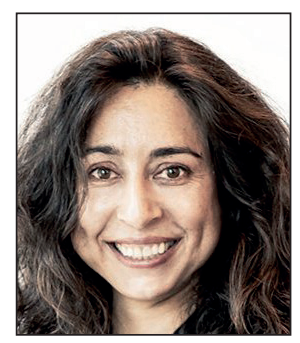

Ana Serrano-Tellería https://orcid.org/0000-0003-1625-4411

Facultad de Comunicación Universidad de Castilla-La Mancha Campus Universitario, 16071 Cuenca, Spain ana.serrano@uclm.es

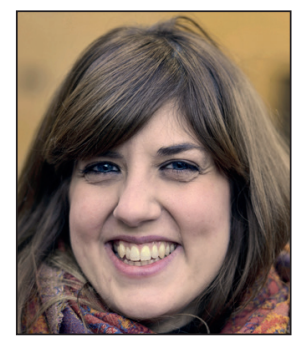

Laura Pérez-Altable https://orcid.org/0000-0003-3114-6371

Universidad Nebrija Facultad de Comunicación y Artes Santa Cruz de Marcenado, 27-31. 28015 Madrid, Spain Iperezal@nebrija.es

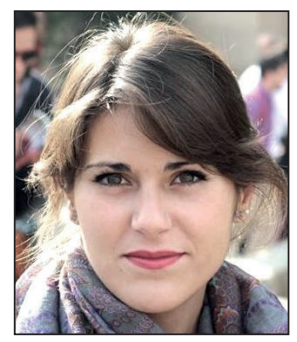

\section{Lucía García-Carretero}

https://orcid.org/0000-0002-1414-3921

Independent scholar

Igarciacarretero@gmail.com

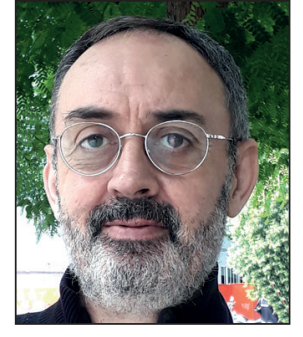

Javier Díaz-Noci $ه$

https://orcid.org/0000-0001-9559-4283

Universidad Pompeu Fabra

Departamento de Comunicación Roc Boronat, 138. 08018 Barcelona, Spain javier.diaz@upf.edu

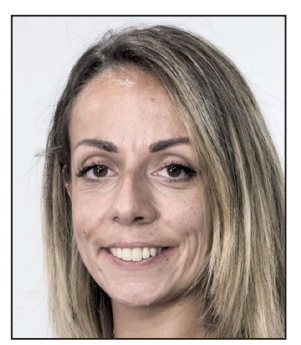

Rosa Pérez-Arozamena https://orcid.org/0000-0002-6125-1255

Universidad Europea del Atlántico Facultad de Ciencias Sociales y Humanidades

Isabel Torres, 21. 39011 Santander, Spain rosa.perez@uneatlantico.es

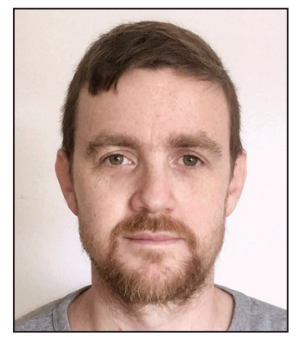

Juan Linares-Lanzman

https://orcid.org/0000-0002-2704-5351

Universitat Oberta de Catalunya Internet Interdisciplinary Institute Parc Mediterrani de la Tecnologia (B3) Av. Carl Friedrich Gauss, 5. 08860 Castelldefels (Barcelona), Spain jlinareslanzman@uoc.edu

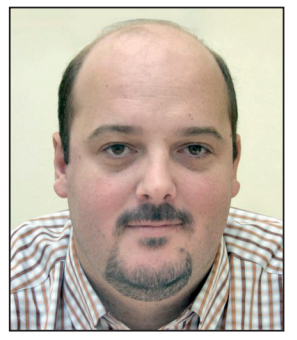

Luis-Mauricio Calvo-Rubio https://orcid.org/0000-0002-4707-5259

Universidad de Castilla-La Mancha Facultad de Comunicación Aulario Polivalente 16071 Cuenca, Spain luismauricio.calvo@uclm.es 


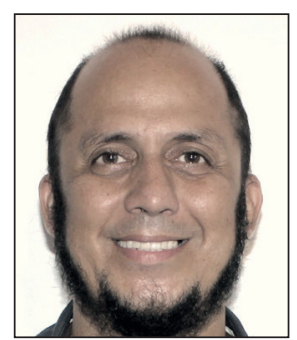

Manuel Torres-Mendoza

https://orcid.org/0000-0002-5844-657X

Universidad Estatal Península de Santa

Elena

Ecuador

manueltomen@gmail.com

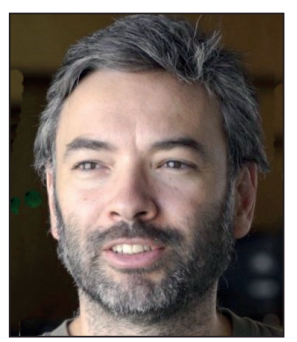

Adolfo Antón-Bravo

https://orcid.org/0000-0003-2437-9863

Univ. Polit. de Madrid, ETSI de Informática, Ontology Engineering Group

Avda. Montepríncipe, s/n

28660 Boadilla del Monte (Madrid), Spain

adolfo.anton.bravo@upm.es

Funding

This paper is one of the results of the research project News, networks, and users in the hybrid media system. Transformation of media industries and the news in the post-industrial era (RTI2018-095775-B-C43) (Mineco/Feder), Spanish Ministry of Science, Innovation, and Competitiveness (2019-2021).

\section{Abstract}

In December 2019, Chinese authorities informed the World Health Organization about a new coronavirus disease that would come to be called Covid-19. The world media began reporting on this new virus and its consequences. However, reports about Covid-19 would not appear in the European and American media until their societies became aware of both the health and economic consequences of Covid-19 in March 2020. This article analyzes the online media coverage of economic inequality. The goal is to understand the formation of the public agenda, based on the impact of the disease on social classes as the main factor generating greater inequality levels, in particular inequality of opportunities as the most remarkable topic during the first stage of the pandemic. According to the first results of this content analysis, the social class divide will be deepened by the pandemic. For this study, a tool was designed to analyze both the manifest and latent content of the items. Using content analysis, an analysis of news published by 33 digital media in both Europe and Latin America from March 14 to April 14, 2020 was conducted. The results of this study show that income inequality appears as the core variable of the problem, although social classes remain important. The imbalanced access to health and education public services also receives continuous coverage in the media. However, poverty as a consequence of this situation remains an uncomfortable issue and tends to be presented in an undramatized way.

\section{Keywords}

Covid-19; Coronavirus; Pandemics; Digital media; Income inequality; Inequality of opportunities; Digital journalism; Spain; Europe; Latin America; Social classes.

\section{Introduction}

On the last day of 2019, December 31, Chinese authorities reported a new coronavirus disease that would later be called Covid-19 to the World Health Organization. It is most likely that the disease started some months before, but it can be assumed that the world media started covering the new virus and its consequences for human health during the very first days of 2020. The consequences are not only health related but also economic: the authorities ordered people to obey a lockdown, first in China and later in practically all the countries on the whole planet. A generalized economic crisis is foreseen, and as a result, it is also taken for granted that an increase in inequality will occur.

However, this would only appear as a specific, focused topic in European and American media when their societies finally became aware of the health problem and a general lockdown was ordered. It was only in that precise moment that concern regarding the economic consequences of the pandemic appeared in the major media in Spain, where the lockdown and the state of alarm began on March 14, 2020. Thereafter, the different types of economic inequality were mentioned regularly. During the first month of the pandemic in Europe and America - the period on which we focus in this article - clear signals of fear regarding an economic slowdown, generalized social crisis, and higher levels of inequity were published in the major digital media of many countries.

The topic of this research is how societies can ensure everyone's wealth and equality of opportunities, and avoid economic resources becoming concentrated in the hands of very few people at the expense of the majority of the population.

\section{Literature review}

Income and, generally speaking, economic inequality arose as a major topic in public opinion around the 1980s, according to several authors (see McCall, 2010, p. 47; Grisold; Theine, 2018). Some other authors (see Schröder and Vietze, 2015) have analyzed the debates on income inequality and poverty in the media since 1946. Obviously, in times of crisis, a more widespread concern appears in the public sphere. This topic was covered extensively by the media after 20072008, following the most recent economic, global crisis (Song; Price; Guvenen; Bloom; Von-Wachter, 2019). Until the Covid-19 crisis of 2020, that was probably the greatest and certainly most globally extended economic crisis in recent history (see, for instance, Krugman, 2009). 
Various scholars are responsible for the renewed interest in this topic during the last crisis: Richard G. Wilkinson and Kate Pickett, two British scholars who worked in the field of health inequality, published The spirit level: Why equality is better for everyone in 2009, demonstrating that more equal societies are happier. These two authors also published another influential book, The inner level: How more equal societies reduce stress, restore sanity, and improve everyone's well-being, in 2019. According to those authors, "since the global financial crash, inequality has moved rapidly up the political agenda" (Pickett; Wilkinson, 2015, p. 132). Nobel laureate Joseph Stiglitz (Stiglitz, 2012; 2019) and Paul Krugman (Krugman, 2009; 2020), as well as various other scholars, such as Branko Milanović (Milanović, 2006; 2012; 2020a) or Janet C. Gornick and Markus Jäntti (Gornick; Jäntti, 2014), have published other influential works on inequality. Probably, however, the author who made income inequality fashionable is Thomas Piketty (Piketty; Sáez, 2003; Piketty, 2013; 2019), with his controversial books Le capital au XXIe siècle and Capital et idéologie, but also the shorter L'économie des inégalités and the World inequality report of 2018. Milanović is the author of a relevant article on the deep impact that the coronavirus pandemic will probably have on the global economy (Milanović, 2020b), published on March 19, 2020, at the beginning of the period treated in this article.

This specific research topic, i.e., economic inequality, and communication are covered by relatively very few people. One of the most remarkable works on this specific topic is M. Petrova's book published just before the crisis of 2007-2008 (Petrova, 2008). Since then, some other authors have dealt with this economic problem and its depiction in the media (McCall, 2010; Duca; Saving, 2012; 2016; Byrne, 2012; Schröder; Vietze, 2015; Harkins; Lugo-Ocando, 2016; Diermeier et al., 2017; Mattelart; Papathanassopoulos; Trappel, 2018). Some of these authors highlight various questions of special relevance: for instance, Diermeier et al. are sure that media "play an important role in biasing individual inequality perception, but also in aggravating people's view on their economic situation at least in the short-run" (Diermeier et al., 2017), which is also a starting point of this article, especially since it focuses on the very first moments of a global problem. The media have undoubtedly helped to place this issue on the public opinion agenda again, and at the same time "news coverage on economic topics affects the perception and understanding of economic issues" (Grisold; Thein, 2017). Some other scholars have focused on the main consequence of inequality: poverty (Fisher; Smeeding, 2016). The role of media in communicating these issues (inequality and poverty) to public opinion has been researched by, amongst other scholars, Clawson and Trice, 2000; Redden, 2011; Bandyopadhyay, 2014, and once again, Harkins and Lugo-Ocando, 2016. Some other scholars have published on the role of social networks in the debate on inequality (Pérez-Altable et al., 2020; Pérez-Altable; Serrano-Tellería; Fernández-Planells, 2020), or focused on other aspects of the media's coverage of income inequality, for instance, entertainment (Coppini; Álvarez; Rojas, 2018).

\section{Goals, research questions, and hypotheses}

This study aims to cover some of the many aspects related to the coverage of economic inequality by online media: both digital-born media and digital versions of legacy media, including the most widely consulted ones in each country. We analyzed their importance to place the issue and its different variables onto the public opinion agenda. Following some authors,

"citizens might have to rely on mediated communication to make sense of economic disparities" (Coppini; Álvarez; Rojas, 2018).

This is a complex problem, so, to some extent, we have tried to focus on some of the most relevant aspects of economic inequality (see, for instance, for the influence of a cross-national analysis and the impact of the digital divide, Fuchs, 2009; for other aspects, Hartmann et al., 2017). We address a single research question:

RQ1. What treatment is given to economic inequality, mainly income inequality, but also wealth inequality and inequality of opportunities, in the media during the period studied?

Related to this general research question, and having discovered some variables, various hypotheses are proposed:

$\mathrm{H} 1$. Online media coverage of the topic is of crucial importance to provide a new impulse to the perception of inequality (Grisold; Thein, 2017) and it does so by indicating a clear relation between:

H1.1. The type of inequality and the gaps related to them

H1.2. The relation between inequality and social classes, which is also a remarkable issue revealed by this analysis and covered extensively by many authors, e.g., Muntaner and Lynch, 1999; Muntaner, Lynch and Oates, 1999; Wolff and Zacharias, 2007; Wilkinson and Pickett, 2009.

H.1.3. The type of inequality and the main topic (especially politics, economy, labor issues, and social issues). A general social gap is predominant during these first weeks of the pandemic, more than the more specific ones related to gender, race, or age.

H1.4. The aforementioned variables, and the reliability of the sources.

H2. Poverty, as a cause and as a consequence of income inequality, was underrepresented and tended to be avoided (according to Clawson; Trice, 2000; Redden, 2011; Harkins; Lugo-Ocando, 2015), before the period of Covid-19. Is it now one of the main consequences depicted by the media, or are there any other changes to the economic, political, and social status quo? In particular, social classes may emerge as the main factor related to inequality. 
H.3. Inequality of opportunities appeared as a major topic during the first stage of the pandemic, most particularly regarding education and health.

H.4. The journalistic treatment of this issue shows some differences when compared with the previous situation.

H.4.1. Expert sources are more reliable, and media tend to consult them.

H.4.2. The lack of certainty regarding the effects of pandemics strengthens the use of op-ed pieces.

H.4.3. Text is the main language and is overrepresented compared with other digital-language resources, such as video or infographics.

\section{Methods}

The method used for this article focused on the treatment of economic inequality related to the Covid-19 pandemic during the first month of lockdown in Europe and America based on a content analysis, to study the media messages of the main online legacy, native, and specialized media in every country. First, we gathered all the pieces containing the terms "inequality" and "coronavirus," "Covid-19," or "pandemic" in the Spanish media, for practical reasons as it was better represented in the sample. Most of the group's researchers are Spanish and are familiar with these media, and an ongoing research project is being developed based on these Spanish media to follow on from previous investigations (Pérez-Altable et al., 2020). Once completed, we checked which countries were mentioned most commonly in the Spanish online media, and proceeded to gather a sample of news items from those countries as well. Once again, the countries most commonly mentioned in those international media were the same ones.

The kind of content analysis we planned is mainly quantitative, and the results we present in this article are also based on measurements, numbers, and graphics. The advantage of this kind of content analysis is that it is a technique that enables not only to describe but also to predict to some extent relations amongst categories and variables (Neuendorf, 2002). To fulfill this goal, we designed a tool to delve into both the manifest and latent content of the news items we analyzed. Even if latent content cannot be measured directly, it can be inferred using some indicators (Neuendorf, 2002), implying a value judgment by the codifiers during the codification process after agreement (Sjøvaag; Stavelin, 2012). Nevertheless, we designed some open, qualitative fields to obtain a fine-grained explanation of this research topic. For instance, gathering further observations using this complementary technique and asking the group's codifiers and researchers to identify the specific topics using their own words, to complement the general ones previously detected and codified in thesaurus-like fields, helped to improve the results and identify relevant terms that may be used in further research studies. Those topics, aggregated using hierarchical trees, are presented in this article as well.

The period of analysis extends from March 12 to April 12, 2020, a period in which the health crisis took form and population lockdown measures were adopted in the countries we examine. We tried to extend the search and data gathering to December 2019, when the pandemic started in China, but the results of a cross-search like the one we needed ("inequality" and "coronavirus") were irrelevant. In other words, European and American media did not consider the economic consequences of the pandemic to be relevant until March 2020, or, at least, they did not cover these consequences extensively until they started to affect nearby societies. Even in the period of this sample, Asian countries or Asia as a whole region is mentioned in barely $1.26 \%$ of the news items.

\subsection{Sample}

The media that were analyzed, except for the United Kingdom - a country in which lockdown measures were adopted later than in many other places - are some of the most important ones in the countries of Southern Europe, Latin America, and North America. Nevertheless, we decided to gather news items from those countries that were most mentioned by the others, starting from Spain: most of the news items obviously refer to their own country or very few others that are highlighted as being more worrying. For this reason, this can be considered to be an intentional sample. We selected, for each country among those chosen (Spain, France, Italy, United Kingdom, United States of America, Mexico, Ecuador, Argentina, and Chile), at least two of the most representative or visited online media and one other specialized on the economy. The sample is larger in the Spanish case, for obvious reasons: we wanted to define the response of the Spanish media to the crisis since we are developing a research project on this topic. The countries and media finally examined are presented in Table 1.

Table 1. Countries and media examined

\begin{tabular}{|l|l|}
\hline Country & Media \\
\hline Spain & ABC, El País, Eldiario.es, La Vanguardia, Expansión \\
\hline France & Le Monde, Le Figaro, Les Echos \\
\hline United Kingdom & The Guardian, The Telegraph, The Financial Times \\
\hline Italy & La Repubblica, Il Corriere della Sera, Il Sole \\
\hline United States & The New York Times, The Washington Post, The Wall Street Journal \\
\hline Mexico & El Universal, SPD Noticias, El Economista \\
\hline Argentina & Clarín, La Nación, Página 12 \\
\hline Brazil & Globo, Folha de São Paulo, Estado de São Paulo \\
\hline Chile & El Mercurio, Bío Bío, La Tercera \\
\hline Ecuador & El Comercio, El Telégrafo, El Universo, GK \\
\hline
\end{tabular}




\subsection{Units}

The units analyzed are those journalistic items published by these digital media in which the pandemic and its effects on economic inequality are linked. To gather those items, we carried out a crossed search using both general search engines, such as Google, and the archives of the media themselves. In the latter case, the internal search engines provided by the media were very irregular. Not all of them allow combined searches, for instance. However, some of the media included a tag on inequality, which was very helpful. We manually discarded those items that did not correspond to the topic of this research. The size of the final sample was $n=714$ items.

The design of the content analysis was aligned with the goals of this research study. Since the pandemic is about to become inequality newsworthy again, the aim is to determine the importance of online media in the formation of public opinion around the studied concept of economic inequality, and the aspects that the media tend to highlight in the treatment of this topic. Due to the appearance of new and disruptive factors such as the global pandemic, the intensive lockdown of the population, and the freezing of economic activity around the world, we decided to link both of these and perform this exploratory study, to be extended in the near future and whilst the situation provoked by the coronavirus disease continues. For this reason, the results presented in this article might be taken as preliminary and requiring further research. The goal is thus to capture a first snapshot of the treatment of the economic effects of Covid-19 on inequality and shed light on which are the relevant issues that the media deliver to public opinion.

\subsection{Categories of analysis}

The different aspects of this analysis are grouped along several dimensions, composed of many categories. The first dimension is related to the source of the news item, feature, or opinion piece. We identify the media, their country, the date when the item was published, and the type of author of the piece. The second dimension determines whether "inequality" and/or "coronavirus/Covid-19" (or even "pandemic") are highlighted in the headlines.

The third dimension is designed to determine the main types of inequality mentioned in the items: income inequality, health inequality, and inequality of opportunities. Regarding individuals, and this explains why we focused on this in previous studies (Pérez-Altable et al., 2020; Pérez-Altable; Serrano-Tellería; Fernández-Planells, 2020; Pérez-Arozamena; Odriozola-Chéné, 2020), income inequality is defined by the OECD as

"as household disposable income in a particular year. It consists of earnings, self-employment, and capital income and public cash transfers; income taxes and social security contributions paid by households are deducted" (OECD, 2020).

To simplify the question on this occasion, we included pay inequality as one of the main income inequalities, which is why the salary gap is mentioned in many items. On the other hand, wealth inequality refers to the total amount of properties and economic resources owned by an individual or group, for instance, a country. Finally, inequality of opportunities occurs when some circumstances block access to social elevators. This is a concern in Spain (see, for instance, El Confidencial, May 16, 2020:

"Si la educación deja de ser presencial, España puede destruir (aún más) su ascensor social" ["If education is no longer presential, Spain might (further) destroy its social elevator"],

which was signaled as a "sticky" country by the OECD in 2018, in which the possibilities of reaching a higher social class are decreasing. Even the World Bank has recognized that

"gender, economic circumstances, geography, and ethnicity can trap large groups of people in poverty, and specifically affect access to basic services among children" (Khokhar, 2014),

and finally, this is precisely the reason we designed our research tool in this way, as we are convinced that

"inequality of opportunity lies at the very heart of discussions about inequality and social welfare" (Guriev; Lankes, 2017).

The health crisis has highlighted at least three aspects of inequality of opportunity: access to healthcare services, access to education, and the importance of research.

The fourth dimension is focused on identifying the most commonly mentioned gaps that cause such inequalities: social class, race (more important in the case of American than European media), gender, and age. We hypothesize that the latter could be one of the most commonly mentioned ones due to the impact of Covid-19 on elderly people.

The fifth dimension analyzes the information treatment. Its variables are the specific framework, macro (a comparison of different groups, usually from a regional or worldwide perspective), micro (referring to a specific social group and the difference between individuals), or both, the context of the geographical area mentioned (the country of the media itself or another country), the main consequence of inequality, i.e., poverty (poverty and the news is a topic deeply developed by academia, see Redden, 2011), but also specific changes in politics and economy, meaning specific measures (which are normally mentioned later on rather than during the very first moments of the pandemic), or a general modification of the social system as we know it. We consider it important to identify the countries that are mentioned in each news item and the main topic mentioned, and added a free-text field to refine the analysis, leaving each encoder to define the specific topic mentioned in their own words. 
From a journalistic point of view, it is important to describe the way in which the story is presented. For this reason, we included the following fields: dramatization, when a story is tinted with emotivity, negative or positive, for instance underlining the sentimental aspects to move the audience, and conflict; fragmentation, when the main event of the story is isolated from a wider context and even trivialized; the function of the story (presenting facts, opinion, or both - usually this includes some kind of interpretative reporting); and whether the facts mentioned in the news item were obtained from press conferences, such as statements, or reports, and the specific sources of information.

Finally, the sixth dimension is focused on how different multimedia resources are used to accompany the text.

\subsection{Coding and intercoder reliability}

The coding process was performed by nine researchers during a month from April 15 to May 15, 2020. A codebook was discussed and approved to establish categories, clarify concepts, and unify responses in the final encoding. Beforehand, a pretest was carried out on 43 of the 714 items ( $6 \%$ of the total) to measure the intercoder reliability. Due to the number of encoders and the large number of categories, we opted to apply Krippendorff's alpha coefficient (Freelon, 2013). Using this coefficient, the degree of intercoder reliability for all the categories and variables was 0.652 , distributed along the six dimensions of the template (Table 2).

Table 2. Intercoder reliability (Krippendorff's alpha coefficient)

\begin{tabular}{|c|c|c|c|c|c|}
\hline $\begin{array}{c}\text { Location of the } \\
\text { item }\end{array}$ & Keywords & Inequality types & Gap type & $\begin{array}{c}\text { Informative } \\
\text { treatment }\end{array}$ & Resources \\
\hline 0.897 & 0.836 & 0.422 & 0.509 & 0.501 & 0.747 \\
\hline
\end{tabular}

In the case of three dimensions (inequality type, gap type, and informative treatment), the result of the intercoder reliability test drove us to improve the codebook to explain to the encoders how to proceed to identify the different categories better and references were provided, and a further test applied to just these three dimensions provided results better than the average, being approximately 0.7 for all of them, sufficient to proceed.

\section{Results}

By arranging the data from the template in a database, we could treat them using combined, advanced searches, comparing and combining several fields to obtain improved results. We are aware that many other methods could be used as well.

\subsection{Rating income inequality versus Covid-19}

"Covid-19" and "inequality" are not balanced in the headlines of the more than 714 items we analyze. While more than $50 \%$ of the items contain "coronavirus" or "Covid-19" in the headline, inequality appears specifically in just $8 \%$ of the headlines, most of which also contain the other search term. Imbalance appears again related to the coronavirus. This is a topic which is treated by media recurrently but intermittently, as shown in previous research studies (Díaz-Noci; Pérez-Altable, 2018; Pérez-Altable et al., 2020; Pérez-Arozamena; Odriozola-Chéné, 2020). Income inequality is the most commonly mentioned in the information provided by Spanish media. This situation is mainly related to social

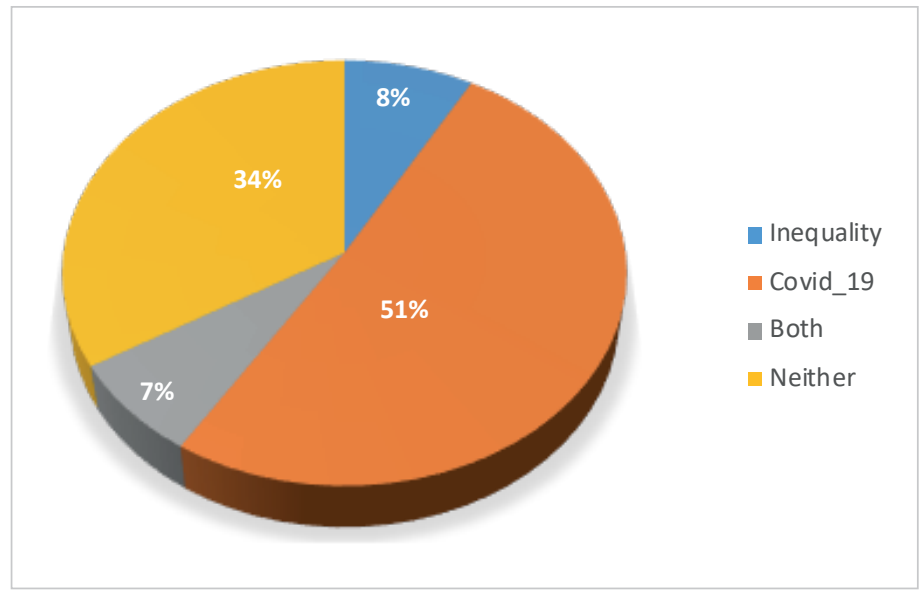

Graphic 1. "Coronavirus" and "inequality" in the headlines issues (problems with access to online education and availability of health resources), ahead of political debates, and economic and labor affairs. The eminently informative pieces represent a minority, whereas analysis through reports, interviews, and chronicles and opinion pieces in columns, essays, short pieces, and editorials are much more widely used. Both groups duplicate the news pieces. On the subject of inequality and the pandemic, the Spanish media also pay special attention to what is happening in Latin America. Even before the period of analysis, EIPaís.com published an analysis entitled "Is Latin America prepared for coronavirus?" [“¿Está Latinoamérica preparada para el coronavirus"], by Jorge Galindo, 29 February 2020.

\subsection{The geographical context of news}

Logically, the media tend to focus on their own country. Nevertheless, this being a global epidemic, other countries are mentioned as well, in more than

Table 3. Coincidence by country of the media and countries mentioned in those media

\begin{tabular}{|l|l|}
\hline \multicolumn{2}{|c|}{ Coincidence (\%) } \\
\hline USA & 85.6 \\
\hline Brazil & 78.2 \\
\hline Mexico & 69.2 \\
\hline Italy & 50.0 \\
\hline Spain & 44.3 \\
\hline France & 40.0 \\
\hline Ecuador & 34.0 \\
\hline UK & 31.6 \\
\hline Argentina & 30.0 \\
\hline Chile & 21.4 \\
\hline
\end{tabular}


half of the items analyzed, while one-third deal with foreign countries and with the media's own society. What is probably more interesting is that some media tend to publish news on inequality in their own country. The degree of coincidence (the number of news items on the country published by each media) is higher in some countries, especially the United States and Brazil (Table 3).

\subsection{Income inequality and unequal opportunities}

Despite being a matter of economic importance, the media tend to focus on social issues, such as salary, unemployment rates, or the conciliation of work and family life. Even politics receives more attention than purely economic issues. The media tend to concentrate on the human consequences of the crisis, not always presenting, at least regarding this specific topic, individual consequences or necessarily personal stories. The figures for the main topics treated by the media are shown in Graphic 2.

One of the first results is the increasing importance of inequality of opportunities when compared with previous analysis (see Pérez-Altable et al., 2020), in which this type of inequality scarcely appeared in the public debate driven by online media and social networks. More than $49 \%$ of the analyzed items from the first month of the pandemic in the analyzed countries and media deal with one or more type of inequality of opportunity. However, this appears in combination with the main types of inequality: income and/or wealth inequality. Almost $67 \%$ of the items deal with these - while the rest did not - and since the treatment given to this subject is not highly specialized, most items ( $40 \%$ of those 476 news items mentioning income and/or wealth inequality) only mention "growing inequality" or "growing social inequality," making it easier for encoders to codify them as "both income and wealth inequality." It is very likely that, as the corpus of items grows over time, this could improve due to both the refined treatment provided by journalists and collaborators and better training of coders.

The kinds of inequality of opportunities dealt with by (or of concern to) the media are clearly shown by this graphic. As a logical consequence of a health major problem, major attention is given to health inequality, or how national healthcare systems respond to the crisis, and consideration of the extent to which diverse strata of the population can access those services, especially in countries where, for economic or political reasons, those public systems are weak, specifically in Latin and North America. As some authors explain, whilst

"in countries with high levels of inequality, citizens tend to overwhelmingly support a more egalitarian distribution of wealth [while at the same time they] often support policies and vote for political parties that reinforce economic inequalities" (Coppini; Álvarez; Rojas, 2018).

Surprisingly enough, the media do not consider the relation of research inequalities with those health problems, now or in the future. Almost one-third of the items analyzed refer to educational problems, especially the digital divide, a problem that will probably become a growing concern in the near future as well.

\subsection{Reason for inequality: What do online media say?}

The most interesting results appeared when we analyzed across more than one field. What do the media consider to be reason for those inequalities? The next graphic shows the results of the

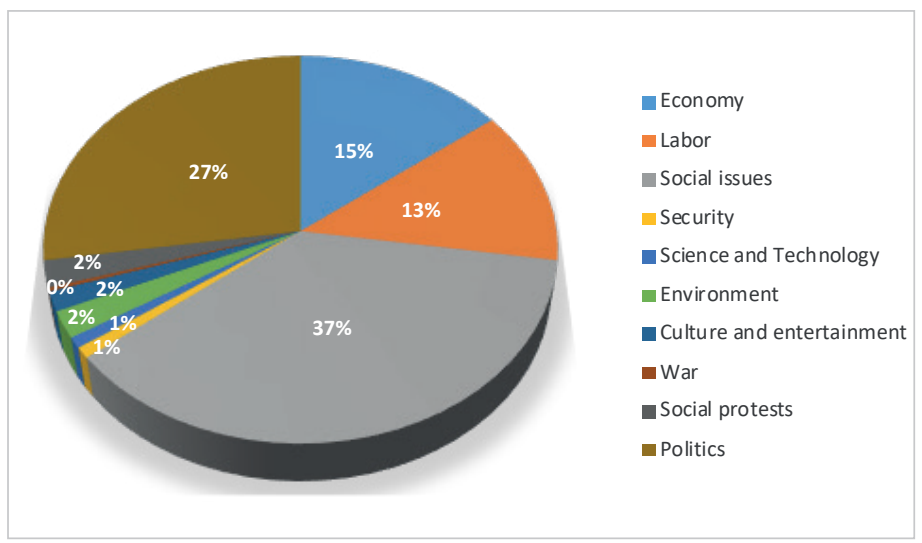

Graphic 2. Main topics related to economic inequality

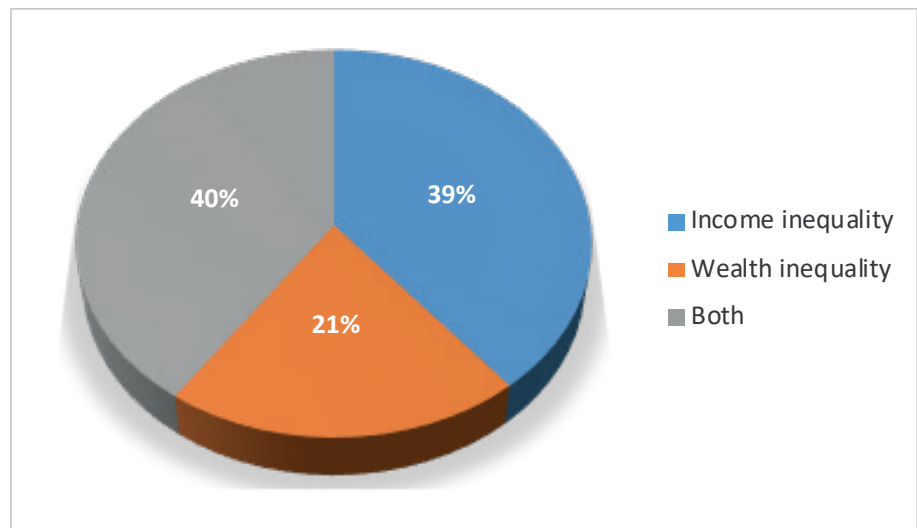

Graphic 3. Type of economic inequality

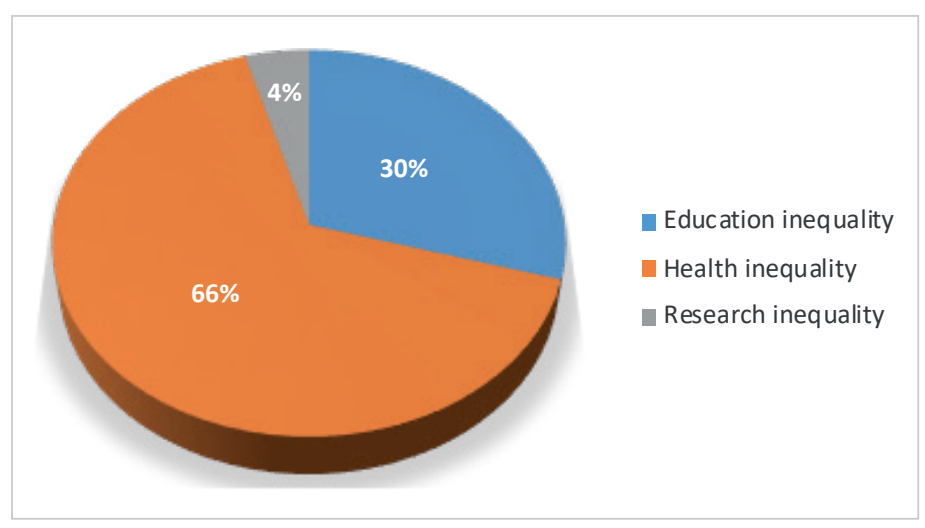

Graphic 4. Type of inequality of opportunities 
treatment given to inequality of opportunities with income inequality, since it is supposed that opportunities are lesser for people with lower salaries or rents, not for people with greater wealth: richer people do not need to care. Outside our period of analysis, for instance, the Agency of Public Health of Barcelona (Spain) demonstrated a lower impact of the disease on that part of the population with greater income or wealth. Nevertheless, the attribution of wealth inequality (most probably with a worse position on the social scale) is also a factor that media highlight as a cause of inequality of opportunities.

Some European countries show greater concern about education, the digital divide, and the difficulty of social mobility, while in Latin America, Ecuadorian media show almost the same level as the British media. In contrast, countries in which inequality is very sharp, such as Brazil, the United States, or Mexico, show a much lower level of concern, which is significant. The range is, in general terms, quite low. Even at its highest levels, news dealing with educational difficulties represents no more than $25 \%$ of the total, and in the worst cases, less than $10 \%$. These are the very early moments of the pandemic, in which schools were closed and the problems of homeschooling arose (Bonal; González, 2020).

As mentioned above, we tried to collect, using a free-text field, the most commonly repeated concepts, to be developed in further research efforts. Categorized by inequality type, the most salient ones are presented below:

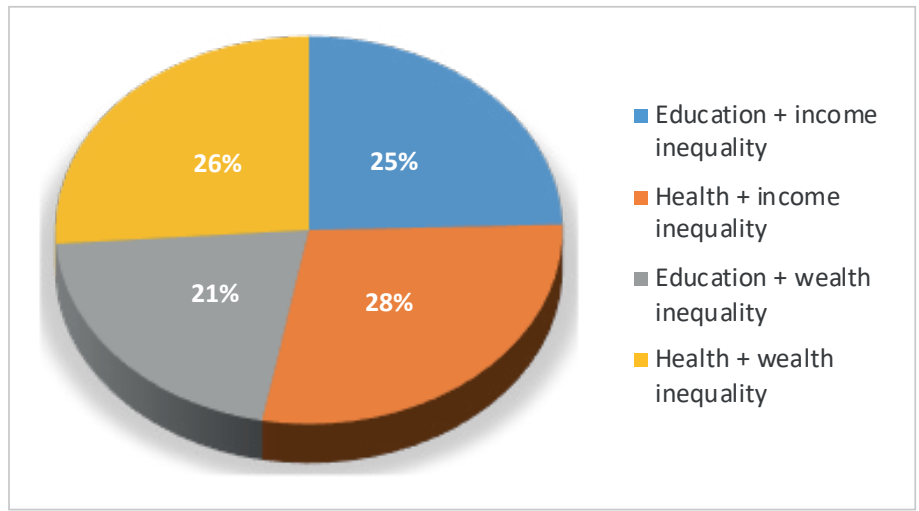

Graphic 5. Inequality of opportunities combined with income and wealth inequality Table 4. Educational inequality in the media, by country

\begin{tabular}{|l|c|}
\hline \multicolumn{1}{|c|}{ Country } & Education (\%) \\
\hline USA & 9.00 \\
\hline Chile & 14.28 \\
\hline Spain & 14.54 \\
\hline Brazil & 10.25 \\
\hline France & 18.18 \\
\hline Argentina & 10.00 \\
\hline Mexico & 10.00 \\
\hline Italy & 20.00 \\
\hline Ecuador & 25.00 \\
\hline United Kingdom & 26.30 \\
\hline
\end{tabular}

Table 5. Topics by inequality type

\begin{tabular}{|l|l|l|}
\hline Income inequality & Wealth inequality & Inequality of opportunities \\
\hline Salary gap & Renting and ownership of homes & Access to education \\
Minimum wage & Access to basic services (e.g., water) & Coeducation \\
Unemployment & Celebrities & Online education \\
Workers' protection & Territorial inequality & Homeschooling \\
& Wealth tax & Health system collapse \\
\hline
\end{tabular}

\subsection{The poor and the rich: The social class gap}

The gap that is most commonly mentioned, either directly or indirectly, is that related to social class. This probably represents a clear trend in the information about the coronavirus disease crisis and inequality, due to both its political and economic implications. This supports the conclusions of some other authors, since obviously "media representations of class, particularly of the poor and the rich, can deeply affect how individuals perceive members of these two socioeconomic groups" (Coppini; Álvarez; Rojas, 2018).

A more detailed analysis combining fields demonstrates that, at these very first moments of the pandemic and considering some countries of the sample (especially American ones), social class inequality combined with racial discrimination is an issue to be followed up in the future. Gender is another issue that, combined with social class inequality, is a subject of concern in the media. Homework appears as an issue highlighted by media during the first weeks of the crisis, since women are assigned greater responsibility for childcare. Indeed, a report on this issue was published by Oxfam in January 2020 (Lawson et al., 2020).

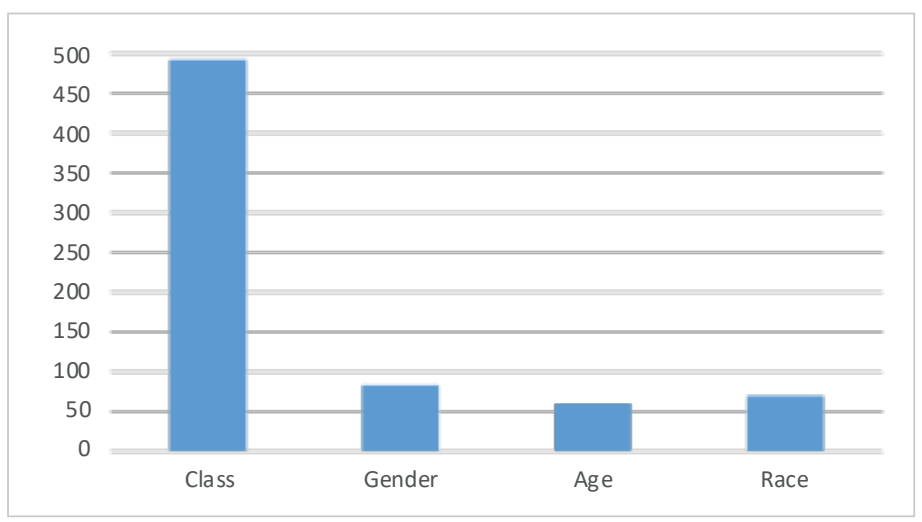

Graphic 6 . The number of items showing the social class gap and inequality in online media 
Once again, some other related terms appeared during the analysis:

Table 6. Topics related to inequality gaps

\begin{tabular}{|l|l|}
\hline \multicolumn{2}{|l|}{ Inequality gaps } \\
\hline Gender & \\
Feminism/chauvinism & Class \\
Violence against women & Digital divide \\
Homework & Job uncertainty \\
Gender pay gap & \\
\hline
\end{tabular}

The main consequence of growing inequality detected by the media is poverty. This simple graphic shows the importance given by media to poverty combined with social class: an expected consequence of the coronavirus crisis will probably be a growing lower class, and maybe an impoverishment of the middle classes, to whom media messages are commonly addressed (Gornick; Jäntti, 2014). Regarding poverty itself, previous research has proved how media, at least in some countries, try to avoid items on poverty, because they are presented as personal, individual stories, and prefer to deal with items on inequality, which are more based on numbers and data, thus being much more impersonally treated (Harkins; Lugo-Ocando, 2016; Fisher; Smeeding, 2016). It is, in this very first moment of the pandemic, in the British media that poverty appears as a more worrying issue, contradicting the study by Harkins and Lugo-Ocando published in 2016. More concretely, a very high percentage $(83 \%)$ of news on inequality and coronavirus in British media mentions poverty as a foreseen consequence, whilst Spain is the country in which media show lesser concern on the topic, followed by Italy and Ecuador. Moreover, a digital newspaper that shows greater concern with poverty and inequality lies outside of our sample: El Periódico de Catalunya. See, for instance, the editorial "Desigualdad y pobreza en España" ["Inequality and poverty in Spain"], February 14, 2020.

\subsection{Portrayals of poverty}

In general terms, poverty as a consequence of the situation is attributed to income inequality: lower salaries or wages, greater risk of becoming poor. See, for instance, Derek Thompson's article on The Atlantic: "The coronavirus will be a catastrophe for the poor," March 20, 2020, and Diego García-Sayán's column in El País:

"Virus no tan 'democrático'. La expansión extendida del virus ha puesto dramáticamente sobre el tapete la desigualdad y los pobres son los más golpeados" [Not such a democratic virus. The wide expansion of the virus has lifted the lid on inequality, and the poor are hit hardest], March 19, 2020.

Considering that salaries are the main income source of a wide range of social classes, namely the lower and middle ones, this is an issue to be followed up in the near future, as are the measures to be adopted to address this problem. In this regard, a month after the explosion of the Covid-19 disease in European and American countries, the specific measures applied to address it receive relatively little attention.

Many related terms appeared during the analysis regarding the consequences, many of them relating to general possible consequences of the crisis:

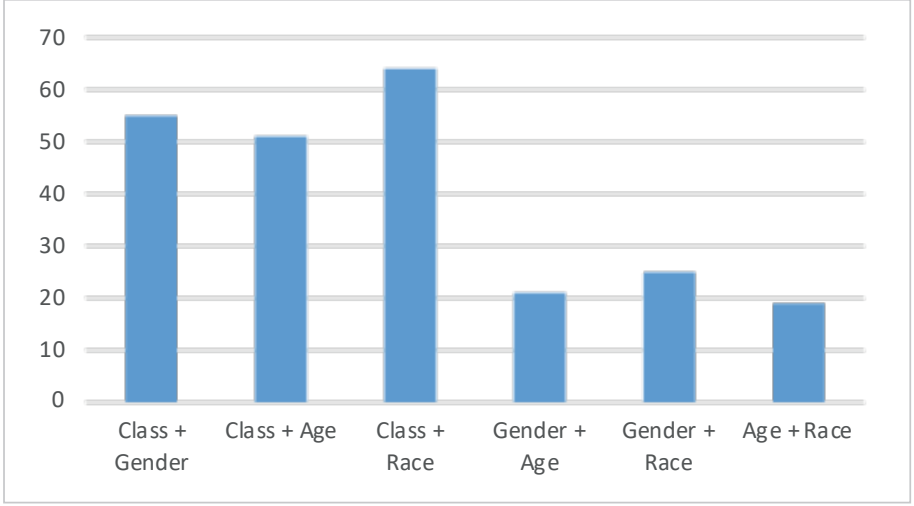

Graphic 7. The number of items showing social gaps and inequality

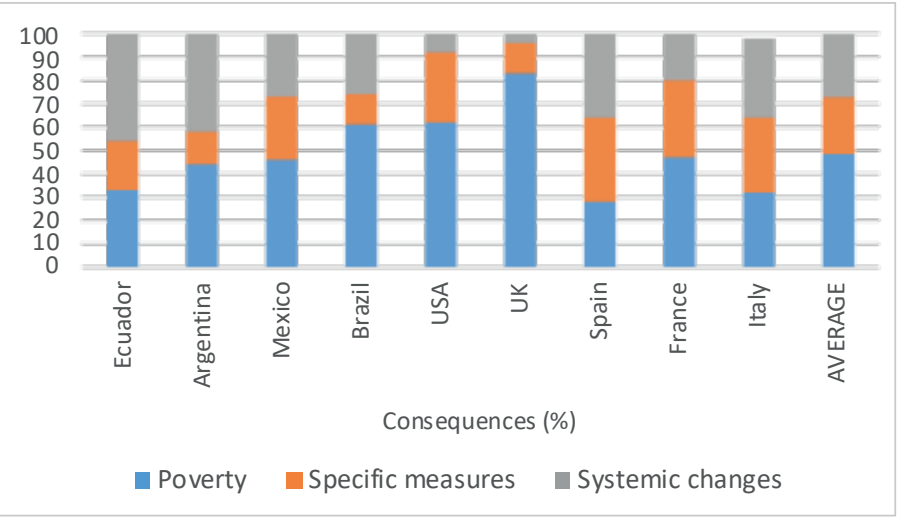

Graphic 8. Consequences of inequality, by country

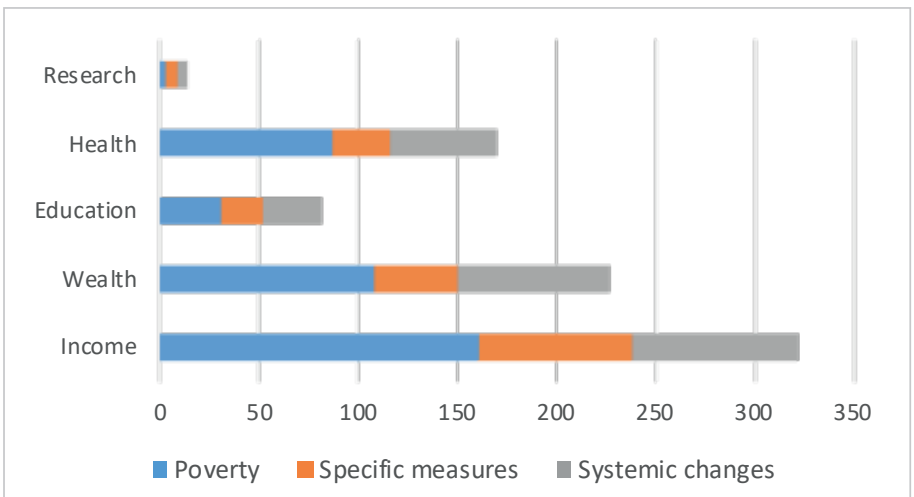

Graphic 9. The number of items including causes and consequences regarding economic inequality 
Table 7. Topics related to the consequences of inequality

\begin{tabular}{|c|c|c|}
\hline \multicolumn{3}{|c|}{ Consequences } \\
\hline $\begin{array}{l}\text { Poverty } \\
\text { Vulnerable groups } \\
\text { Recession }\end{array}$ & $\begin{array}{l}\text { Specific measures } \\
\text { Economy activation } \\
\text { Taxation: } \\
\text { Universal basic income } \\
\text { Minimum wage } \\
\text { Coronabonds and recovery bonds } \\
\text { Constituency processes } \\
\text { Election processes } \\
\text { Legislative proposals } \\
\text { Reindustralization }\end{array}$ & $\begin{array}{l}\text { General changes } \\
\text { Climate change } \\
\text { Change in lifestyle } \\
\text { Capitalism (crisis) } \\
\text { International cooperation } \\
\text { Liberalism (crisis) } \\
\text { Human rights } \\
\text { Political centralization/decentralization } \\
\text { Welfare state } \\
\text { Globalization } \\
\text { Governance } \\
\text { Migration } \\
\text { Privacy } \\
\text { Telecommuting }\end{array}$ \\
\hline
\end{tabular}

The most popular and well-known scholars on economic inequality were warning of some of these undesirable consequences just before the coronavirus crisis. For instance, Paul Krugman published a new book called Meeting globalization's challenges in January 2020.

\subsection{Journalists at work: resources}

From a journalistic point of view, most items were written by journalists, but almost a third of the pieces analyzed are opinion items: inequality augmented by the coronavirus crisis is an issue that columnists have dealt with from the very first moment. A good example is Larry Elliott's "The coronavirus crisis may lead to a new way of economic thinking," The Guardian, March 22, 2020.

A finer analysis reveals which kind of items journalists and collaborators or writers prefer, in other words, the balance between information and opinion pieces regarding the different aspects of inequality. When it comes to income inequality, education, and health inequality, which affect individuals, information is predominant. When dealing with wealth inequality, which refers to individuals but also large social groups and nations, opinion writers tend to write slightly more:

The sources used by journalists are predominantly press conferences and declarations, while reports and specific data are used much less as the main source. This is quite surprising if we compare the kind of people mentioned as the main personal source of information: experts, for instance, are mentioned in $28 \%$ of the items we analyze, followed by politicians $(15 \%$, with technical staff attached to institutions representing only $2 \%$ of the mentioned sources), supranational organisms such as the World Health Organization (WHO) and NGOs (5\%). Drilling down to specific topics, such as income inequality, the percentage of experts grows significantly: $48 \%$ of all items use them as a source.

The frame of the information is predominantly micro, except for the case of Italian and British media, which seem to prefer a combined view comparing micro and macro perspectives, maybe to minimize the impact on their society or to

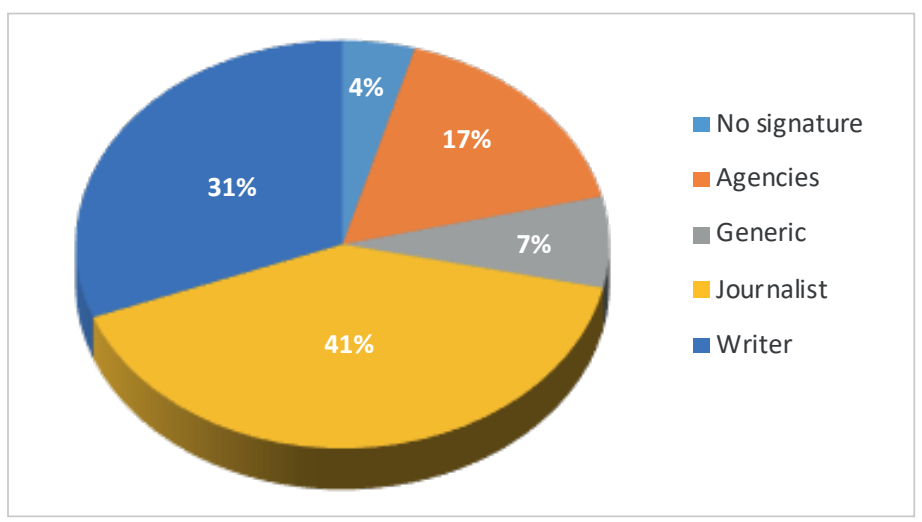

Graphic 10. Authorship of items on inequality and coronavirus

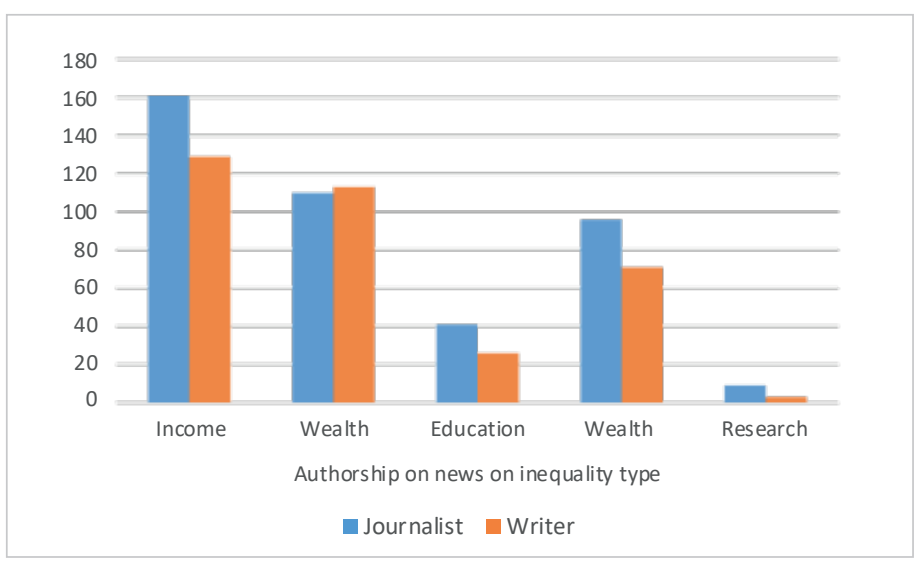

Graphic 11. Authorship of news on inequality type

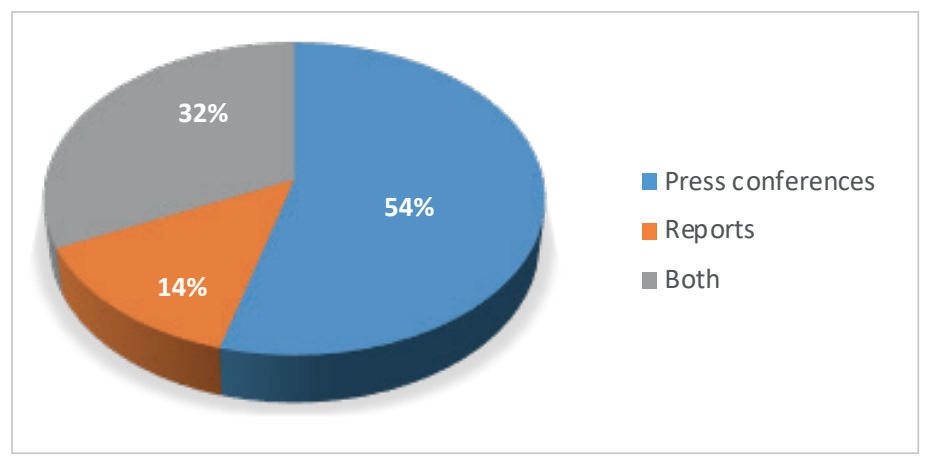

Graphic 12. Sources of information 
contextualize inequality as part of a wider panorama. Anyway, in general terms, a huge majority of items deal with a micro perspective (59\%), although the average shows an interesting tendency towards a combined treatment $(33.56 \%$ of the items).

Of particular interest is not only what media treat in their pieces, but also how they present them. We have advanced some results above. There is a clear predominance of information ( $43 \%$ of the items are purely informative, while $24 \%$ contain some opinion or interpretation as well), and precisely a third of the pieces gathered are purely opinative. This is not a low number, however. Fragmentation and dramatization are both low: news items are contextualized in the general framework of the pandemic, and journalists prefer not to deal with personal, emotive example cases. This is common in the media treatment of economic inequality, as explained by Harkins and Lugo-Ocando (2016). The specific percentages of fragmented and dramatized pieces are shown in this graphic. Dramatized pieces are more abundant in reports and more interpretative pieces. The more dramatized consequences are class issues (67\% of all dramatized pieces), poverty ( $58 \%$ of all dramatized pieces), income inequality (41\% of all dramatized pieces), and gender gap inequality ( $20 \%$ of all dramatized pieces). Education, on the contrary, is a topic that presents low dramatization: only $9 \%$ of this kind of piece are dramatized, while $91 \%$ of them are not. Another factor to consider is that all the newsrooms are now empty, with most journalists working from home. As a curiosity, in Argentina (Clarín), a comment from journalists was apparent:

"[T]e jodo con este material para ver si es posible un rincón en la web, lo que puedas y si podés" ["If you can, put this material in some corner of the web, whatever and wherever you can"].

https://www.clarin.com/sociedad/coronavirusargentina-confederacion-bioquimicos-ofrecered-laboratorios-hacer-estudios_0_v28mFhk1z. html

Text is very predominant; audio scarcely appears, nor video, pictures, and infographics. Their relatively high number is a logical consequence of dealing with inequality in general, numeric terms.

This is related to dramatized pieces. More generally, images are much more predominant, having in many cases a merely illustrative function. Concerning the overall use of resources, among 714 pieces, 524 employed pictures, 64 videos, 19 infographics, 8 galleries, 7 surveys, and 1 audio. In this sense, pieces that use different resources are present as follows: 73 of those that employed pictures, 9 of videos, 3 of infographics, 1 of galleries, 1 of surveys, and 1 of audio, revealing a

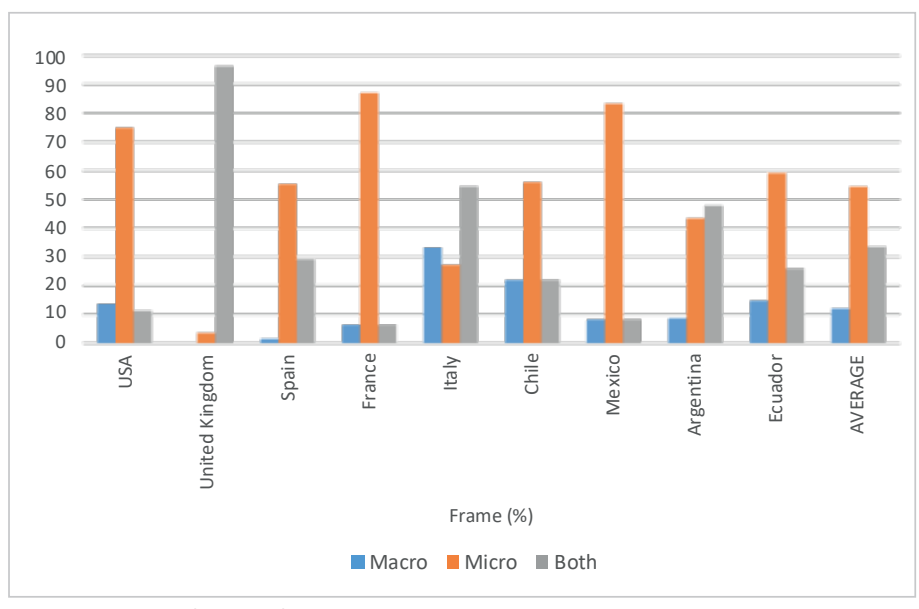

Graphic 13 . The frame of news on inequality, by country

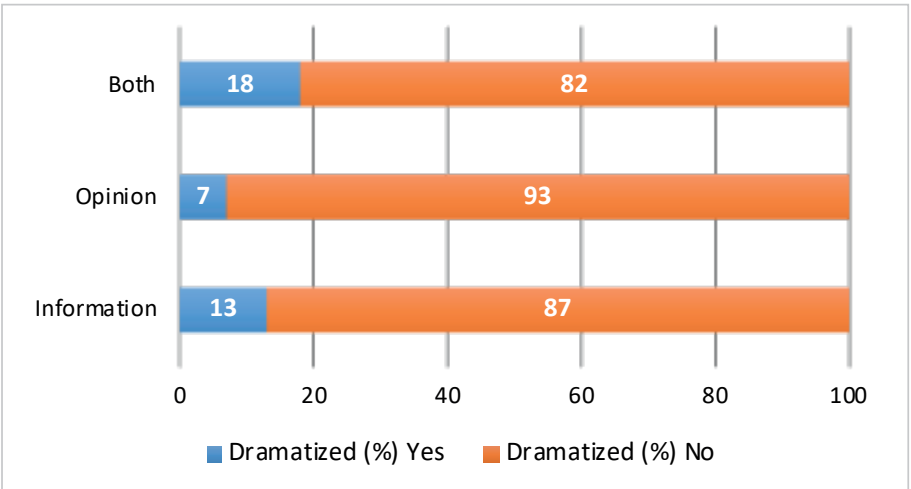

Dramatized pieces



Fragmented pieces

Graphic 14. Treatment of items

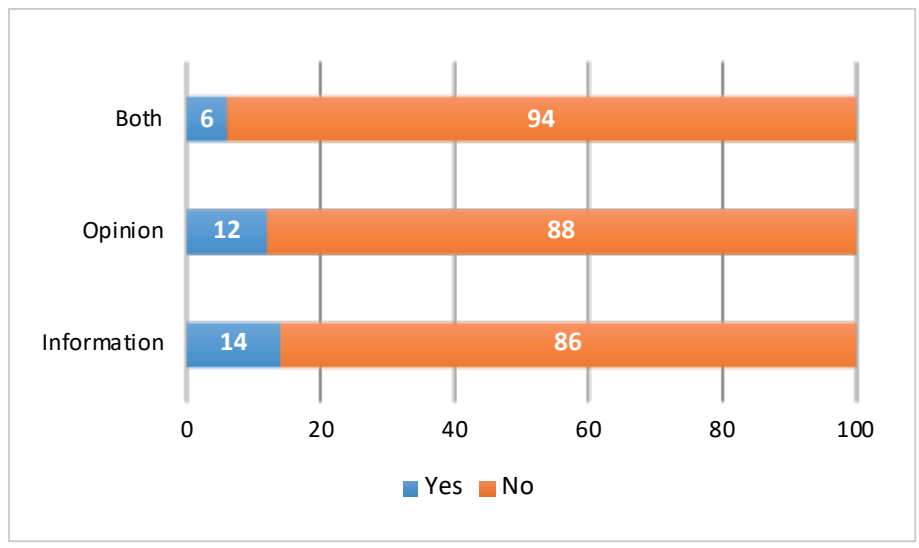

Graphic 15. Dramatized pieces using resources other than text 
pattern in their level of use similar to the overall results mentioned before.

Delving into concrete uses, the average shows a combination of two graphical resources in 89 pieces (mainly a picture with another, with videos and infographics being preferred) then three (11), four (1), and five resources (1). Among the media, Lanacion.com leads the ranking with 29 pieces (out of 46) that combined more than one resource, followed by Elpais.es (19 of 48), Eldiario.es (12 of 34), Lavanguardia.com (10 of 43), Clarin.com (6 of 30), Thetelegraph.co.uk (2 of 5), and Theguardian.com (3 of 31). The scarce use of surveys (7) is mostly related to opinion pieces, while video or pictures from galleries and social networks (Twitter threads) were used instead of pictures in a few pieces. In some European countries, such as France, the use of these resources is reduced. Several pictures appear with some articles; notwithstanding the approach (information, opinion, or interpretation), their use is purely decorative.

Additionally, most of the pieces where both concepts are developed belong to the opinion genre and are authored by writers/collaborators rather than journalists. In informative pieces, such ideas are dealt with only in passing, without any explanation or depth. The relation between income inequality and this medical issue is depicted by French media as a continuation of the previous economic crisis, a situation that will widen the gap between social classes, a scenario where rich people become richer while those with a worse financial state will end up in a worse position than before the pandemic. These thoughts are presented for France, of course, but for the whole world as well.

British media deployed in most pieces internal and/or external links to their pieces and external resources. Elpais.es, Eldiario.es, and Lavanguardia.com also provided these, albeit in only a few pieces. It should be emphasized that there is an increasing tendency for media to include the use of internal and internal links in their style guide.

\section{Discussion}

This quite preliminary, descriptive and indicative study depicts some trends in the treatment of economic inequality accentuated by the pandemic that must be confirmed in the future following the evolution of the disease and the economic situation, as well as the measures adopted. All of these results should be contrasted with the vision of this issue provided by the media of these countries, which are those identified by the international community as being more sensitive in Europe and America. However, Africa, and even Asia, are geographical areas that are scarcely mentioned during the first month of the crisis by the media we examine, although the few items found on the topic are extremely concerning (see, for instance, Ayesha Jacob's

"The coronavirus and Africa: Exposing our vulnerabilities and inequalities," (The Guardian, March 22, 2020).

This is another issue to be followed up in further investigations: the role of distant countries - including China, in which the disease started and one of the most powerful economic forces in the world - and in some African countries, where endemic poverty results in the most unequal societies in the world.

Despite the many limitations of this study, it provides some clues and further directions to deepen understanding of this important topic in the future. It shows how online media are dealing with this specific problem: the growing social inequality after a ten-year-long crisis (2008-2018) at the gates of a major, worldwide recession period provoked by the pandemic. It shows that income inequality appears as the core variable of the problem and that social class remains important. In previous work, we explained that

"to a great extent, the debate promoted by media is linked to the middle, or even, upper middle classes" (Pérez-Altable et al., 2020).

We are inclined to believe that this is the case in 2020 as well, but a more longitudinal study on the consequences of the Covid-19 crisis and its depiction in the media is required to arrive at more definitive conclusions. Anyway, a cross-examination of our database fields sheds some light on how the media have started to link major topics and secondary issues, and on the type of sources they trust most: experts and scholars, first, even though if most items are based more on statements than on reports, and, secondly, politicians. To some extent, the first hypothesis thus takes shape, but a longer period is required for deeper analysis.

The second hypothesis is partially supported, since poverty is the main possible consequence of growing inequality caused by Covid-19, but it tends to be depicted with little dramatization. Major changes in social classes are foreseen, and this is a quite implicit issue appearing in the majority of news items, while a possible impact on the current status quo is widely covered, mentioning many major topics such as globalization, capitalism, and liberalism but very few specific 
measures. This may change when analyzing a larger sample and once the health crisis comes under control, but during these first moments of the lockdown, the picture is quite general.

What is clear, and we guess that we have sufficient evidence to believe that this will also be a constant issue in the future, is the shift that highlights the importance of inequality of opportunities (H3), especially education and access to technology. In other words, the impact of the digital divide seems to be a topic that the media will continue to concentrate on in the coming months. Inequality of opportunities is a type of inequality that is now competing with income inequality for the attention of the media, while wealth inequality appears to be more related to a transnational, comparative perspective.

It is too soon to foresee the deepest consequences that an increment of inequality in the world will have on the political and social system as we know it. It is clear that people

"care most about income inequality when it becomesa societal problem" (McCall, 2010, p. 50),

and the predictions of reputed scholars on the topic are bleak: Branko Milanović authored an article in Foreign Affairs on March 19, 2020, stating that

"The real pandemic danger is social collapse, as the global economy comes apart, societies may, too."

Some pieces we examined are even more direct: Owen Jones, one of the most famous journalists of The Guardian, titled a piece published on March 14, 2020, this way:

"We are about to learn a terrible lesson from coronavirus: inequality kills."

As a consequence, many scholars, e.g., Duca \& Saving (2017), have wandered about the extent to which inequality leads to polarization. According to Maria Petrova, the way in which mass media cover inequality and distribution affects how people vote, at least in the United States of America (Petrova, 2008), an effect that becomes more visible when society has a high democratic development index, another aspect that could be considered in our research (see also Casero-Ripollés, 2020). Political biases and how they have been influenced by media, focusing in particular on liberalism and neoliberalism, is another aspect requiring careful consideration and that has been treated by, e.g., Byrne, 2012. The digital divide will certainly have an impact on this, starting with education, in which the cruelty of unequal resources for children (i.e., Internet access or access to computers and tablets) due to income inequality has been revealed from the very first moments of the pandemic. This was a well-known factor before this major crisis exploded:

"One can conjecture that higher incidence of media variables -such as newspapers, radios, and televisions- and higher access to ICTs - such as higher internet usage, and deeper telecommunications' penetration- can be associated with lower levels of inequality" or not (Bandyopadhyay, 2014, p. 11).

Courtois and Verdegem affirm that

"In today's information society, access and mastery of online resources are indispensable participatory prerequisites" (Courtois; Verdegem, 2016, p. 1509).

When the time comes to speak about specific measures or real, deep, lasting changes to society and our lifestyle, there will be a chance to refine our analysis categories. This is the case for taxation, for instance, or universal basic income. Many of these appeared in our free-text fields, so we have sufficient material to adjust our analysis.

\section{Limitations and further research}

This study is limited in scope, in terms of the period and number of countries analyzed and the online media chosen. Due to time limitations, not all countries were considered, so it is probably important to continue with this analysis in the near future by incorporating at least two more: Portugal in Southern Europe, due to its singular response to the crisis, and Canada in North America. There is also a need for a larger sample size, covering a greater period. We do not doubt that this will modulate the results of this preliminary study. In our humble opinion, however, it is important to confirm how online media are treating this topic in a wide range of countries and media from the very beginning, and also for the group to decide whether to give more or less weight to the different variables.

This is a research problem which can only be examined longitudinally along all its dimensions, to confirm that "the longterm trend in income inequality has been driven by two main factors: a surge at the top end in income and wealth; and, at the bottom end, a combination of reduced wealth and slower income growth during good times and a fall in income during bad times" (Fisher; Smeeding, 2016, p. 32).

A more nuanced analysis will probably reveal that the imbalanced access to health and education public services will probably receive some continuous coverage in the media. Poverty is a consequence of the current situation, but this is an uncomfortable issue and tends to be presented in an undramatized way, being a central issue that media will inevitably face in the future. How they will approach this task is another research question we could study.

The characteristics of the treatment of this issue must be examined in more detail as the crisis continues, at least until a vaccine is produced and the population can be immunized, and the economy refloats again. It is uncertain when either of these will occur, but the problem has probably just started. 
Much further research is needed on this topic. Some other methods will also be considered. For instance, since many authors (Grisold; Theine, 2017; Coppini; Álvarez; Rojas, 2018) insist on the importance of how the media shape people's perception of the importance of income inequality, and some other aspects of economic inequality, a survey of news consumers would be important. At least in the case of Spain, the country of most of the authors of this article, it may be feasible to carry out some in-depth, probably semistructured interviews with journalists of the Spanish online media analyzed in this sample to deepen the coverage of economic inequality in the times of the pandemic. More perspective is needed to design and perform this triple analysis based on content analysis, surveys, and in-depth interviews. However, the goal of this article was just to confirm the main aspects of the general topic of economic inequality that are more visible on online media in some countries of Europe and America.

We leave for further stages of our research project a perspective on the treatment of the different media individually and those from each country. On this occasion, however, we have focused on the topics treated and their treatment to provide more general results. A headline from the The New York Times provides a good overall synthesis:

"As coronavirus deepens inequality, inequality worsens its spread," (Max Fisher and Emma Bubola, March 16, 2020),

We intend to continue this work, while the purpose of this short study was to confirm which categories may work and how this tool might reveal some clues regarding how this specific topic is treated by the media.

\section{References}

Bandyopadhyay, Sanghamitra (2014). Are mass media and ICTs associated with inequality and poverty? London: Queen Mary University of London.

http://personal.Ise.ac.uk/BANDYOPS/ICT_Ecineq_RElvol22.pdf

Bonal, Xavier; González-Motos, Sheila (2020). Desigualdades de aprendizaje en confinamiento. Barcelona: Universitat Autònoma.

http://blogs.uab.cat/aprenentatgeiconfinament

Byrne, Rebecca-Jolene (2012). Framing income inequality in the media: Is there a liberal or neoliberal bias. Master Thesis, Georgia Southern University.

https://digitalcommons.georgiasouthern.edu/cgi/viewcontent.cgi?article=1622\&context=etd

Casero-Ripollés, Andreu (2020). "Impact of Covid-19 on the media system. Communicative and democratic consequences of news consumption during the outbreak". El profesional de la información, v. 29, n. 2, e290223.

https://doi.org/10.3145/epi.2020.mar.23

Clawson, Rosalee A.; Trice, Rakuya (2000). "Poverty as we know it: Media portrayals of the poor". The public opinion quarterly, v. 64, n. 1, pp. 53-64.

https://doi.org/10.1086/316759

Coppini, David; Álvarez, Germán; Rojas, Hernando (2018). “Entertainment, news, and income inequality: How Colombian media shape perceptions of income inequality and why it matters". International journal of communication, v. 12, pp. 1651-1674.

https://ijoc.org/index.php/ijoc/article/view/6205/2322

Courtois, Cédric; Verdegem, Pieter (2016). "With a little help from my friends: An analysis of the role of social support in digital inequalities". New media \& society, v. 18, n. 8, pp. 1508-1527.

https://doi.org/10.1177/1461444814562162

Dencik, Lina; Leistert, Oliver (eds.) (2015). Critical perspectives on social media and protest. Between control and emancipation. London: Rowman \& Littlefield. ISBN: 9781783483365

Díaz-Noci, Javier; Pérez-Altable, Laura (2018). "Dealing with the crisis: Income inequality and digital media in the Basque Country (2008-2018)". In: International congress on cyberjournalism, Bilbao, November 2018. Bilbao: University of the Basque Country, pp. 86-101. ISBN: 9788413190754

Diermeier, Matthias; Goecke, Henry; Niehues, Judith; Thomas, Tobias (2017). Impact of inequality-related media coverage on the concerns of the citizens. DICE Discussion Paper, n. 258, Düsseldorf: Düsseldorf Institute for Competition Economics (DICE). ISBN: 9783863042578

Duca, John V.; Saving, Jason L. (2017). "Income inequality, media fragmentation, and increased political polarization”. Contemporary economic policy, v. 35, n. 2, pp. 392-413.

https://doi.org/10.1111/coep.12191

Fisher, Jonathan; Smeeding, Timothy M. (2016). "Income inequality". In: The poverty and inequality report 2016. Stanford: The Stanford Center on Poverty and Inequality, Pathways, pp. 32-38.

https://inequality.stanford.edu/sites/default/files/Pathways-SOTU-2016.pdf 
Freelon, Deen (2013). "ReCal OIR: Ordinal, interval, and ratio intercoder reliability as a web service". International journal of internet science, v. 8, n. 1, pp. 10-16.

https://www.ijis.net/ijis8_1/ijis8_1_freelon.pdf

Fuchs, Christian (2009). "The role of income inequality in a multivariate croos-national analysis of the digital divide". Social science computer review, v. 27, n. 1.

https://doi.org/10.1177/0894439308321628

Grisold, Andrea; Theine, Hendrik (2017). "How come we know? The media coverage of economic inequality". International journal of communication, v. 11, pp. 4265-4284.

https://ijoc.org/index.php/ijoc/article/view/6669

Guriev, Sergei; Lankes, Hans-Peter (2017). Transition report 2016-17. London: European Bank for Reconstruction and Development. ISBN: 9781898802457

Harkins, Steven; Lugo-Ocando, Jairo (2016). "All people are equal, but some people are more equal than others. How and why inequality became invisible in the British press". In: Servaes, J.; Oyedemi, T. The praxis of social inequality in media. Lanham etc.: Lexington, pp. 3-19. ISBN: 9781498523462

Hartmann, Dominik; Guevara, Miguel R.; Jara-Figueroa, Cristian; Aristarán, Manuel; Hidalgo, César A. (2017). “Linking economic complexity, institutions and income inequality". World development, v. 93, pp. 75-93.

https://doi.org/10.1016/j.worlddev.2016.12.020

Khokhar, Tariq (2014). The data minute: What is inequality of opportunity?. World Bank Blogs.

https://blogs.worldbank.org/opendata/data-minute-what-inequality-opportunity

Krugman, Paul (2009). The return of depression. Economics and the crisis of 2008. New York: W. W. Norton \& Company. ISBN: 9780393337808

Krugman, Paul (2020). Arguing with Zombies: Economics, politics, and the fight for a better future. New York: W. W. Norton \& Company. ISBN: 9781324005018

Lawson, Max; Butt, Anam-Parvez; Harvey, Rowan; Sarosi, Diana; Coffey, Clare; Piaget, Kim; Thekkudan, Julie (2020). Time to care. Unpaid and underpaid care work and the global inequality crisis. Nairobi: Oxfam. ISBN: 9781787485419 https://doi.org/10.21201/2020.5419

Milanović, Branko (2006). Global income inequality: What it is and why it matters. [s.l.]: World Bank. https://www.un.org/esa/desa/papers/2006/wp26_2006.pdf

Milanović, Branko (ed.) (2012). Globalization and inequality. Cheltenham, Uk; Northampton, MA: Elgar. ISBN: 9781 849804523

Milanović, Branko (2020a). Capitalism, alone: The future of the system that rules the world. Cambridge, MA: Harvard University Press. ISBN: 9780674987593

Milanović, Branko (2020b). "The real pandemic danger is social collapse. As the global economy comes apart, societies may, too". Foreign affairs, March 19, 2020.

https://www.foreignaffairs.com/articles/2020-03-19/real-pandemic-danger-social-collapse

Muntaner, Carles; Lynch, John; Oates, Gary L. (1999). "The social class determinants of income inequality and social cohesion". International journal of health services, v. 29, n. 4, pp. 699-732.

https://doi.org/10.2190/HNC9-BEFF-7UWL-92Y2

Neuendorf, Kimberly A. (2002). The content analysis guidebook. Thousand Oaks, CA: Sage. ISBN: 9780761919773

OECD (2020). Income inequality (indicator). https://doi.org/10.1787/459aa7f1-en

Pérez-Altable, Laura; Pérez-Arozamena, Rosa; Linares-Lanzman, Juan; Odriozola-Chéné, Javier; Fernández-Planells, Ariadna; Serrano-Tellería, Ana; Díaz-Noci, Javier (2020). "The crisis, the people and the media: How digital public opinion debates on economic inequality". In: Peña, Simón; Meso-Ayerdi, Koldobika. Active audiences: Empowering citizens' discourse in the hybrid media system. Barcelona: McGraw-Hill, pp. 131-143. ISBN: 9788448620035

Pérez-Altable, Laura; Serrano-Tellería, Ana; Fernández-Planells, Ariadna (2020). "Audiencias activas y desigualdad de ingresos: análisis exploratorio de la conversación en Twitter". Hipertext.net, n. 20, pp. 1-12.

https://doi.org/10.31009/hipertext.net.2020.i20.01

Pérez-Arozamena, Rosa; Odriozola-Chéné, Javier (2020). “El tratamiento de la desigualdad económica en cibermedios internacionales: análisis de contenido desde la perspectiva del nuevo sistema híbrido". Hipertext.net, n. 20, pp. 13-30. https://doi.org/10.31009/hipertext.net.2020.i20.02 
Petrova, Maria (2008). "Inequality and media capture". Journal of public economics, v. 92, n. 1-2, pp. $183-212$. https://doi.org/10.1016/j.jpubeco.2007.04.004

Pickett, Kate E.; Wilkinson, Richard G. (2009). The spirit level: Why more equal societies almost always do better. London: Allen Lane. ISBN: 9781608193417

Pickett, Kate E.; Wilkinson, Richard G. (2015). "Recalibrating Rambotti. Disentangling concepts of poverty and inequality". Social science and medicine, n. 139, pp. 132-134.

https://doi.org/10.1016/j.socscimed.2015.07.005

Pickett, Kate E.; Wilkinson, Richard G. (2018). The inner level: How more equal societies reduce stress, restore sanity and improve everyone's wellbeing. London: Penguin. ISBN: 9780525561224

Piketty, Thomas (2004). L'économie des inégalités. Paris: La Découverte. ISBN: 9782707185679

Redden, Joanna (2011). "Poverty in the news". Information, communication \& society, v. 14, n. 6, pp. 820-849.

https://doi.org/10.1080/1369118X.2011.586432

Schröder, Martin; Vietze, Florian (2015). “Mediendebatten über soziale Ungleichheit, Armut und soziale Gerechtigkeit seit 1946 und wie sie mit Einkommensungleichheit zusammenhängen". Zeitschrift für soziologie, v. 44, n. 1, p. 42-62. https://doi.org/10.1515/zfsoz-2015-0105

Sjøvaag, Helle; Stavelin, Eirik (2012). Web media and the quantitative content analysis: Methodological challenges in measuring online news content. Convergence: The international journal of research into new media technologies, v. 18, n. 2, pp. 215-229.

https://doi.org/10.1177/1354856511429641

Stiglitz, Joseph E. (2019). People, power, and profits: Progressive capitalism for an age of discontent. New York: W. W. Norton \& Company. ISBN: 9780241399231

Wilkinson, Richard G.; Pickett, Kate E. (2009). "Income inequality and social dysfunction". Annual review of sociology, v. 35, pp. 493-511.

https://doi.org/10.1146/annurev-soc-070308-115926

Wolff, Edward N.; Zacharias, Ajit (2007). Class structure and economic inequality. Working paper n. 487. Annandale-on-Hudson, NY: The Levy Economics Institute of Bard College.

http://www.levyinstitute.org/pubs/wp_487.pdf

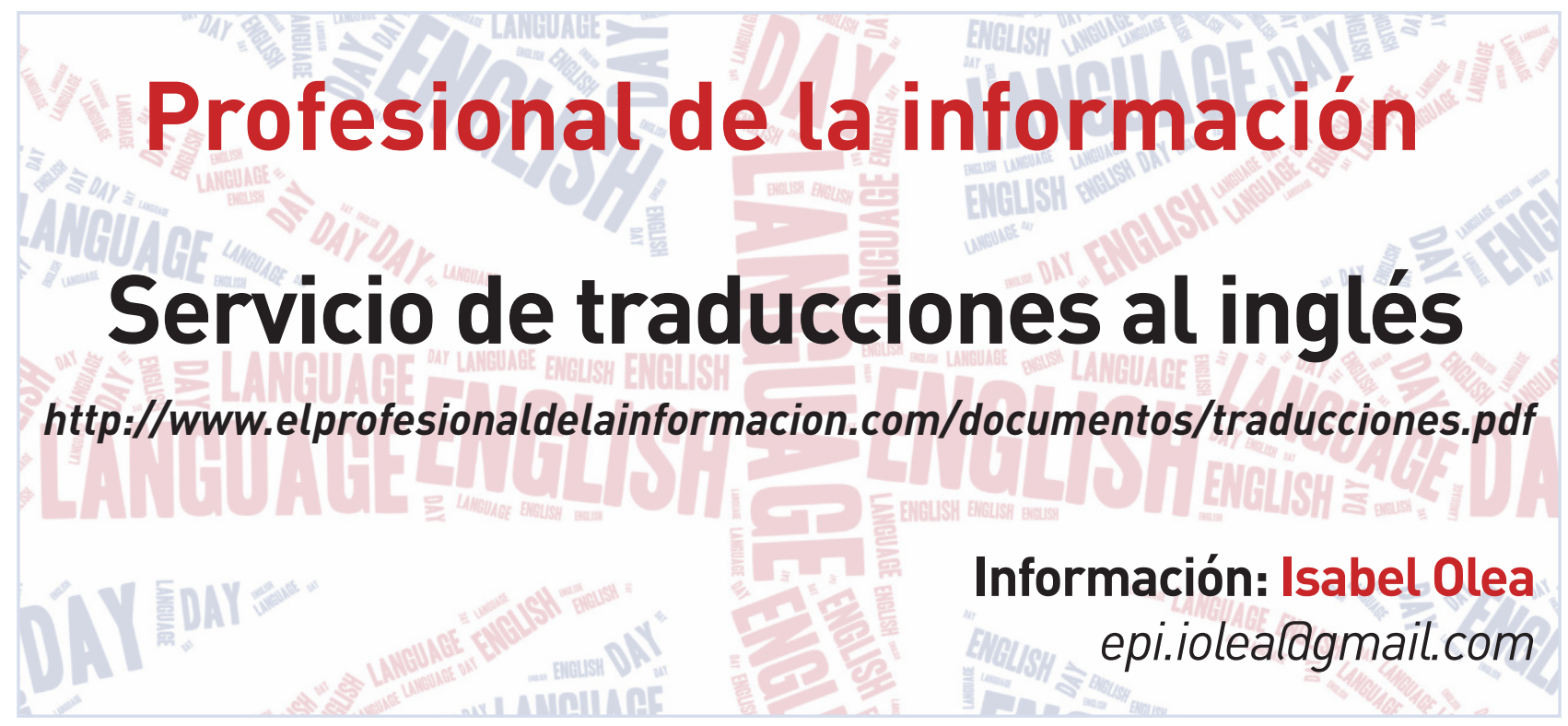

